\title{
Loving the Immigrant as the Premier Jewish and Christian Ethic
}

\author{
Kendra Sofia Blandon \\ University of Florida \\ Faculty Mentor: Anna Peterson, Department of Religion
}

\begin{abstract}
The modern term "immigrant" does not appear in the original Jewish and Christian scriptures. While concepts of nations, borders, and formal immigration did not develop until long after Biblical times, several Hebrew words existed for foreigners. An analysis of the words gēr, nēkār, rēa, zār, and tôšāb reveals how foreign strangers were regarded by the Jewish people. The established covenant commanded Jewish people to "love your neighbor (rēa) as yourself" (Lev. 19:18). This commandment, located in the middle of Leviticus and the middle of the Holiness Code, is considered by many to be the highest development of ethics in scripture. Still, a concentrated debate about passages in both Testaments continues among academics and religious leaders, especially about the Christian obligation to follow the laws of the land, but dissent if the laws are unjust. An examination of Jewish and Christian texts, world views, and contemporary scholarship is needed to determine how, if at all, believers should respond to the present immigration crisis in the United States. This paper shares some of the many stories in scripture about migration, concluding that the story of Jewish and Christian scripture, and indeed, the story of mankind, is one of migration.

Keywords: Immigrant; Jewish Studies; Christian Studies; Exodus; Leviticus; Holiness Code; Borders; Neighbor; Jewish Law; Church; Sojourner
\end{abstract}

\section{Introduction}

This work seeks to understand what the Jewish and Christian scripture say about the presence and treatment of foreign nationals over two thousand years ago and examine how these moral teachings are interpreted. As prophets, their families, and other Biblical characters traversed the Middle East, the writings of those journeys in the Torah reveal different categories for migrants, including nokrî, zār, and gēr, while the noun tôšāb refers to one who relies on Israel for his or her wellbeing. While the scriptures build on each other, it would be irresponsible to refer to a JudeoChristian identity or ethic as the faiths differ on major ideological issues. This paper will analyze the scriptures independently, note developments, and conclude that loving the immigrant is the premier ethic in both the Jewish and Christian scripture and faith. 


\section{Jewish Scripture}

The command to love the stranger, the non-believer, appears in Jewish scripture thirty-six times, making it the most repeated commandment. The treatment of foreign nationals is based on three key moments in Jewish history. The first is that the Jews were an oppressed alien/slave class in Egypt, a foreign land (Exodus 22:21). Second, God always seeks to liberate the disenfranchised (Exodus 23:9). Third, God's covenant with Israel is "contingent on all members of the community benefitting, regardless if they are Jewish or not" (Deuteronomy 16:11) There is an important moral lesson to the liberated Jewish people after Exodus: love the stranger, for they, too, were a stranger in Egypt.

\section{Terms for Non-Jewish People}

At the time of the Torah's writing, there were no formal borders or immigration customs and enforcement agencies. While today's immigration crisis in the United States would be inconceivable to those living thousands of years ago, the language in the Bible can help us begin the conversation about morality and social ethics as it relates to welcoming and loving the stranger, by first defining who the stranger is. Several terms used in Hebrew scripture refer to the people we might today call refugees or immigrants.

The gēr were "sojourners, migrants, immigrants, and displaced persons." They are dependent strangers that have been displaced from their original kinship group. The gērîm category applied to people outside of their place of origin who rely on a new group for their wellbeing, usually having suffered some form of persecution and social conflict. Gēr comes from the related verb gûr, which means "to dread." Having escaped a life of hardship and fear, the gēr come to live under the protection of a new nation (Spina 2016). Interestingly, Spina notes a gēr migrant can be displaced within their own country. The patriarchs of Israel are gērîm as they fled Egypt, and Israel began to identify as a nation of migrants before they settled in Canaan (Heimburger 2018).

Second, the nēkār and nokrî -- "foreigners, strangers, and outsiders" -- are visitors from other regions, usually entering Israel for business or a personal matter. They are not resident aliens, do not intend to stay, remain unassimilated and do not join Israel (Heimburger 2018). The nēkār, nokrî are defined by their present settled residency and do not depend on Israel. Hoffmeier reports that this term can be applied to enemy attackers, the penniless, and undesirable squatters. He finds a legal distinction between the gèr and foreigners that were not invited to stay by an Israeli citizen, inferring that the benefits and protection of Israel over foreigners only applies to 
"legal" foreigners that are formally or informally sponsored by Jewish citizens (Hoffmeier 2009). Still, Hebrew scriptures never describe monitoring borders, legal immigration processes, or the arrests and deportations of foreigners, making his conclusion improbable.

Conservative lawmakers use Hoffmeier's work to support strict immigration policy because he notes that Jewish texts do not say one must welcome all strangers. This is correct, as the Hebrew scripture does have a word for foreign enemies bent on cruelty and the destruction of the Jewish people. The foreign zār do not have the same rights as resident aliens and have broken crucial national laws (Hoffmeier 2009). According to Jewish scripture, one does not have an obligation to zār, "one who is bent upon your extermination" (Patterson 2018). However, Patterson notes that Jewish texts do not say entering Israel without documentation or invitation is an action that harms a Jewish citizen.

Only two modern Biblical translations, the Lexham Expanded Bible and the New English Translation, use the English word "immigrant" for the Hebrew terms gēr, nēkār, zār, and tôšāb. Besides those two translations, scholars agree that the English word immigrant does not quite fit the Biblical context. Sojourner and foreigner are the English word most used in the Bible to describe these people, appearing nearly a hundred times in both Jewish and Christian scripture. It is important not to impose modern notions of "immigrant" ethnicity, polity, or race on Hebrew words, because Jewish scripture is not interested in the birthplace, language, and culture of the gēr, nor how long they intend to stay in Israel (Awabdy 2014). "The arrival and presence of sojourners were not a threat to Israel's national identity; rather, their presence was fundamental to its very meaning" (Carroll Rodas 213). The laws implemented by Jewish leaders to care for the sojourner strengthen Israel's national identity.

\section{Exodus and Leviticus}

Exodus details the exile of the Jewish people from their own land and how God revealed himself. Leviticus is largely instructional, detailing how the Jewish people should follow God's Law. Exodus 22 and 23 are often-cited passages that describe the important commandment of loving the stranger, reminding the Israelites that they were enslaved foreigners in Egypt. David Patterson expounds on the original Hebrew text to examine ethical issues present in Exodus. The phrase Atem yedaatem et nefesh hager, usually translated as "because you were strangers in Egypt," with an emphasis on nefesh, the soul, expressed that knowing another's soul means that 
every soul is bound together. Every human is a child of Adam, and thus we are essentially and spiritually tied to the souls of every other human being (Patterson 2018).

The Holiness Code laid out in Leviticus 17-26 details how one can achieve holiness, including dietary rules and circumcision. Understanding Leviticus reveals key information about the rule on loving one's neighbor. Levine notes the changing emphasis in each section of Leviticus, from dietary restrictions and ritual impurities in Lev 1-16 to ethnical uncleanliness in Lev 17-27 (Levine 1989). Leviticus 19 is the central book of Leviticus and of the Pentateuch as a whole, forming the literal and metaphorical center of Jewish scripture. Leviticus lays out positive and negative responsibilities and creates an expanded version of the Ten Commandments. To many, Leviticus 19 is "the highest development of ethics in the Jewish scripture" (Bosman 2018).

Leviticus 19:18 is perhaps one of the most-cited Biblical passages, drawing out important themes of letting go of anger and choosing forgiveness instead:

You shall not take vengeance or bear a grudge against any of your people, but you shall love your neighbor (rēa) as yourself: I am the Lord. (Lev 19. NRSV)

Leviticus 19:18 does not use a term for foreigner. Some take this to mean that this commandment refers to only one's neighbor, someone they are physically close to, similar to, and share daily life with. While that may be the contemporary understanding of the word "neighbor," a deeper study of the word reveals the opposite. Genesis 11 first introduces the term rēa, neighbor, at the origin moment of different linguistic and cultural nations at Babel. When humanity was one and had one language, the people went forth "and they each said to his rēa" to build brick homes and cities. After the world was divided, conflict broke out and nations were created. Yet, in Genesis 38, Judah, an Adullamite, calls Hirah, a Canaanite, his rēa. As one scholar puts it "those people who have been reading the verse as meaning just-your-own-kind were misreading... and completely missing its total context in the Bible" (Bosman 2018 p. 577). Your neighbor includes those of other nations, languages, culture, etc. Leviticus 19:18 calls on believers to love every person as they love themselves and God, for they are all connected.

Leviticus 19 may provide an answer to the age-old question: what is love? There is no universal answer to this question, but in the context of Hebrew Scripture, "love," Ahava means more than just romantic or familial love. It refers to God's reciprocal love for Israel, and in the Near East love was "wholly community-related and for that reason also a political term that 
resonated with loyalty" (Gerstenberger 1996). Importantly, the command details how Jewish people will live as God's chosen people. By taking special care of vulnerable and oppressed people, including non-native residents and foreigners, Jews were and are remembering their own history and "completing" the self (Bosman 2018). By imitating God's love on earth, Jewish leaders believe that we can manifest God's holiness on Earth.

Neighborly love means "Holiness is thus achieved not through exclusion or separation but by an inclusive attitude, thereby including those who are different from you" (Bosman 2018 p. 588). The discussion of Chapters 1-27 in Leviticus theorizes that the Jewish laws regarding the requirements of a holy life were clarified in Leviticus, which is dated to the postexilic period. The Jewish faith calls for a holy inclusio, a nation of the faithful (Bailey 2005). By following the laws of Leviticus, and especially the call to love the neighbor, a common person of Israel can achieve the same holiness ascribed to priests.

\section{Deuteronomy and Psalms}

In Deuteronomy and Psalms, God is revealed as one who loves the sojourner. Psalms provides devotions to God and expands on the Jewish worldview. It establishes the rights and obligations of leadership to guard, protect, judge, and rescue. Hebrew scripture repeatedly notes that nations will be judged by God by how they treat orphans, widows, and migrants (Psalm 82, 127, 146). God judges the powerful by how they treat the most vulnerable. Kings and governments are warned not to forget that they answer to a higher power and that when "temporal authorities claim independent sovereignty to the neglect of their duties ... the Earth quakes" (Heimburger 2018).

Deuteronomy 7:8 discloses that the people of Israel were not chosen for any special reason. They were saved only because the Lord loved them and kept an oath to the forefathers of Israel. "To abuse authority and wield power self-interestingly over the disadvantaged is to forget Israel's plight and bondage in the land of Israel and the Lord's mercy to Israel in rescuing them" (Wessel 2017). The social justice laws lay out specific, tangible ways that the leaders of Israel must protect these three categories of people, including prohibiting overharvesting crops. It expresses the need to ensure people are fed and have security over their person.

Deuteronomy offers important lessons on striking the balance between inclusion and exclusion. After all, a nation must have a way to determine who its citizens are and have different rules for members and non-members. Excavations of burial grounds in Israel reveal that 
at the time of Hezekiah's Passover festival, there was a population boom following the conquest of Samaria in 720 BCE when refugees flooded to Jerusalem (Na'aman 2008). Scripture explains that gēr were to be incorporated into Israel socially, joining the Jewish people in feasts and events, though not necessarily required to abide by dietary laws (Glanville 2017). It was the obligation of Israel to share joy, abundance, and community. After three generations, gēr that demonstrate a commitment to the Jewish people and to Yahweh could be admitted into the assembly by following God's law to be fully integrated and part of Jewish kinship groups (Awabdy 2014).

Regardless of whether the gēr adopted Jewish beliefs and practices, they were to be welcomed. Deuteronomy presents a triangle of kinship connections between Yahweh, Israel and the gēr. The legal covenant set forth "can be no more broken or altered than the blood relationship" between familial groups (Glanville 2018). Glanville offers an analysis of Deuteronomy 10:12 - 11:11 and reveals that the triangular bonds between the three are satisfied by the covenant, by kinship, and by a profound emotional connection. It is not enough for Israel to care for the gēr physically, but Israel's love for the stranger ought to have an emotional dimension of empathy and kindness.

\section{Christian Scripture}

The teachings of Jesus call on believers to create a new world united by belief. While openness to outsiders is central to a Christian ethic of evangelization, scripture reveals differently constructed reasons for loving the stranger (Carroll Rodas 2013). While religious Jews believe the self is completed and when you love others, Christianity's interpretation of Christ's sacrifice "presupposed the completeness of humankind and of the self" (Bosman 2018). The new law established by Paul placed a larger emphasis on individual belief rather than exhortations to leadership and action. While Christian scriptures reveal new developments in ethics, loving the stranger and immigrant is still central to Christian theology.

\section{The Gospel of Matthew}

While the historical and written Jesus did not work with migrants, he did work with the stranger, a term used to encapsulate the needy, hungry, sick, and imprisoned. While Matthew's stranger is not equal to "immigrant," Jesus warns that rejecting the "least of these brothers and sisters of mine" (Matt 25:40) is to reject Christ himself. These exhortations are reminiscent of 
Yahweh's testimony in Leviticus that to reject a widow, orphan, or foreigner is to turn away from Yahweh.

In the Gospels, Jesus appears as a stranger, unknown and unrecognizable even to those who followed him closely. He walked as a stranger on the road to Emmaus (Luke 23), confuses people at the events of transfiguration (Luke 9, Mark 9), is misidentified as a gardener (John 20), appears at the shore to his disciples after resurrection (John 21), and appears as a stranger in other similar events. These moments of confusion and revelation throughout the Gospels create the narrative that God is powerful and all knowing, he can exist in the peripheries of society. The lesson of these apparitions is revealed in Matthew 25.

The Judgment of Nations explains that in the final days, people will be judged based on how they treated the hungry, thirsty, poor, naked, sick, and the stranger. God will appear as the "least of these" at any point in one's life (Matthew 25). This lesson of humanism emanates throughout the Gospels, calling to put aside differences and realize the value in human life. The philosophy of seeing yourself and others in the image of God is the concept imago dei. In an era of intense fragmentation and isolationism, individuals may struggle to see themselves in the eyes of a poor migrant. The present immigration crisis might present a divine challenge "nudging forward a fresh look at ... strange faces through which God can be encountered and proclaimed in words, deeds, and ways that are life-giving for the many and not just for the few?" (Suna-Koro 2019). Loving and welcoming the "least of these" brother and sisters struggling in immigrant detention camps and centers may be the way to realize imago dei and see God manifested.

\section{The Gospel of Luke}

Luke's Gospel aims to strengthen the belief in Christ and to announce the good news that non-Jewish Gentiles can enter God's kingdom. In the parable of the Good Samaritan, a lawyer asks Jesus how to attain eternal life. Jesus responds with the story of three men passing a victim of violent crime. The priest and Levite, though genealogically chosen by God ignore the beaten man. Samaritans had committed grave acts against the Jewish people, including scattering bones in a temple during Passover, a crime against God's law defiling holy ground. Still, the parable of the Good Samaritan in Luke 10:25 leads the Jewish lawyer to understand that even a Samaritan, in caring for the beaten man, his neighbor, was showcasing exemplary behavior worthy of the kingdom of God. The dialogue between Jesus and the lawyer functions to demonstrate the difficult principle from the Sermon on the Plain (Luke 6:27-28) (Proctor 2019). 
This parable reveals that genealogical outsiders can still exemplify Christian values. The prevailing Greco-Roman culture was based on reciprocity, the belief that you should be kind to neighbors because you never know when you will need something. Jesus speaks against this in Luke 14:12 when he says one ought to invite the lame, poor and crippled to the banquet, not the rich neighbor who can reciprocate. The parable of the Good Samaritan rejected the notion that one must only be "neighborly" to those of a certain class. This parable creates a radically different world for the Jewish lawyer and, of course, future Christians.

For Luke, answering the question "Who is my neighbor?" is just as easy as determining the identity of one's enemy. By doing the latter, one immediately establishes the limits of the former category and so gains the knowledge necessary to satisfy Jesus's understanding of the demands that Leviticus 19:18b would impose on his followers (Proctor 2019).

Nothing in Luke 16:19-31 suggests Lazarus meets the modern definition of an immigrant, since there is no indication he is from a foreign land. However, the Hebrew gēr extended even to displaced persons within Israel. Similarly, the Greek term for "poor" referred to one's social standing within a larger community, since borders and kinship groups were not so clearly defined. The "poor" in the time of Jesus were not exclusively those without economic means. To be poor meant to be outside circles of influence, to be dishonored by others, and to be overlooked even when one is "known" to the rest. Lazarus is representative of a class of people that will live forever in "the bosom of Abraham," individually protected and provided for in all eternity (Luke 16:25).

Even though Lazarus was likely a "citizen" of his country, he was not accepted. Jones' geographically and historically based book on migration provides much needed answers to understand how Lazarus fits into the immigration crisis, for walls restricting movement are the precursors to formal borders. "The distinction between inside and outside, between native and foreigner... with little regard for what effect it might have on the other and without questioning why there is a distinction between "us" and "them" ... [creates] the direct and structural violence of borders" (Jones 2016). The parable of the Rich Man and Lazarus is a warning that ignoring those outside our walls and borders is an error that erects the "chasm" between Heaven and Hell, which Moses, the Prophets, and the risen dead have forewarned (Luke 16:26-31). 


\section{Conclusion}

Both Jewish and Christian scriptures provide theological grounding for welcoming and aiding immigrants. Remembrance of Jewish persecution as strangers in the land of Egypt is an essential identity marker. To provide for and feel kinship with the foreigner among you is the path forward to achieving a holy life. The Christian doctrine of loving the stranger dictates that loving one's enemy as oneself is the way to enter God's kingdom. "God as revealed in Jesus Christ is seen as the ultimate migrant, people are migrants on the earth, the church is a pilgrim church, the Scripture is all about migration, church history is all about migration, boundary crossings, being on the way" (Frederiks 2016). Christian scripture reveals the spiritual and historical basis for loving the poor and, by extension and definition, the migrant. While Christian churches interpret these rules differently, the scriptural basis for not tolerating inhumane laws and caring for the poor migrant imago dei is definite. Careful attention to Jewish and Christian scripture shows that loving the immigrant as you love yourself and God is the primary way to lead a holy life and enter God's kingdom.

\section{Acknowledgements}

Thank you to Dr. Anna Peterson at the University of Florida for her expertise, mentorship, and extraordinary guidance in this research project. Her probing questions and invitations to meet scholars opened countless doors for my academic and professional development. I am ever grateful to Dr. Peterson and know that she will continue to deeply inspire hundreds of students as she inspired me.Thank you to my friends and family who have supported my passion for the intersections of social justice, faith, and the law. To my colleagues and loved one working towards immigrant justice at Blandon Law, the Samuel Proctor Oral History Project, Baker Interfaith Friends and Freedom for Immigrants, thank you for your solidarity and friendship.

\section{References}

Awabdy, Mark A. (2014). Trans. Mohr Siebeck. "Immigrants and Innovative Law: Deuteronomy's Theological and Social Vision for the 'ger'. Forschungen zum Alten Testament 2. Reihe 67.

Bailey, Lloyd R. (2005). Leviticus-Numbers. Smyth \& Helwys Bible Commentaries.

Bosman, Hendrick L. "Loving the Neighbor and the Resident Alien in Leviticus 19 as Ethical Redefinition of Holiness." Hebrew Scripture Essays, vol. 31, no. 3, 2018, pp. 571-590

Carroll Rodas, M. D. (2013). Christians at the Border: Immigration, the Church, and the Bible. Grand Rapids, Michigan: Brazos Press.

Frederiks, M., Nagy, D. (1965). Ed. Religion, Migration, and Identity: Methodological and Theological Explorations. Boston: Brill. 
Gerstenberger, Erhard S. (1996). Leviticus. A Commentary. Old Testament Library. Louisville: Westminster.

Glanville, Mark R. (2018). Adopting the Stranger as Kindred in Deuteronomy. Atlanta: SBL Press.

Griffith, M. (2020) "Welcoming the Stranger: Immigration and American Values." Lecture at the University of Florida. Schudder Lecture Series. February 6, 2020.

Heimburger, Robert W. (2018). God and the Illegal Alien: United States Immigration Policy and a Theology of Politics. Cambridge, United Kingdom; New York, NY: Cambridge University Press.

Hoffmeier, James K. (2009). The Immigration Crisis: Immigrants, Aliens, and the Bible. Wheaton, Illinois: Crossway.

Jones, Reece. (2016). Violent Borders: Refugees and the Right to Move. London, UK: Verso.

Levine, Baruch. (1989) Leviticus. Philadelphia: Jewish Publication Society.

Na'aman, Nadav. (2008) "Sojourners and Levites in the Kingdom of Judah in the Seventh Century BCE." Ancient Israel and Its Neighbors: Interaction and Counteraction; Collected Essays. Vol 1: 23779.

Patterson, David. (2018) “A Jewish Perspective on Ethical Issues Surrounding the Refugee Strangers." CrossCurrents 67 (3).

Proctor, M. A. (2019) "Who is My Neighbor?" Recontextualizing Luke's Good Samaritan (Luke 10:2537). Journal of Biblical Literature 138 (1): p. 203-219

Spina, Frank A. (2016). 'Israelites as Gērîm, 'Sojourners,' in Social and Historical Context.” The Word of the Lord Shall Go Forth. 321-35. Winona Lake, Ind.: Eisenbrauns.

Suna-Koro, K. (2019). "God, Strangers, and Jugs of Water: Taking Matthew 25 to Immigration Courts in the First World." Dialog: A Journal of Theology 58 (4): pp. 242-245.

Wessel, Keith C. (2017) Charity Toward Widows in Early Christian Communities. University of Florida. 